\title{
Obesity and Liver Cancer in Japan: A Comprehensive Review
}

\author{
HIROKI NISHIKAWA ${ }^{1,2}$, SHINYA FUKUNISHI $^{1}$, AKIRA ASAI ${ }^{1}$, \\ SHUHEI NISHIGUCHI ${ }^{3}$ and KAZUHIDE HIGUCHI ${ }^{1}$ \\ ${ }^{1}$ The Second Department of Internal Medicine, Osaka Medical and Pharmaceutical University, Takatsuki, Japan; \\ ${ }^{2}$ Department of Internal Medicine, Division of gastroenterology and hepatology, \\ Hyogo College of Medicine, Nishinomiya, Japan; \\ ${ }^{3}$ Kano General Hospital, Osaka, Japan
}

\begin{abstract}
Lifestyle-related factors play a major role in the development of cancer. In recent years, obesity has become widespread in the world and has attracted attention not only as a cause of diabetes mellitus and atherosclerotic diseases but also as a factor in carcinogenesis. In Japan, the number of obesity-related malignancies has been increasing with the westernization of lifestyle. On the other hand, it is estimated that there are more than 10 million nonalcoholic fatty liver disease (NAFLD) patients in Japan. NAFLD is classified into simple fatty liver and nonalcoholic steatohepatitis (NASH), and 10-20\% of NASH patients will progress to liver cirrhosis and 2-3\% of them will develop hepatocellular carcinoma (HCC) per year. Research interest in metabolism-associated liver cancer has been increasing in recent years. Here in this review, we will comprehensively summarize the current knowledge with regard to the relationship between obesity and HCC in Japan.
\end{abstract}

In 2018, 18.1 million people worldwide were diagnosed with cancer, and about 9.6 million people died from it (1), which is a significant increase from 2002 (10.9 million cancer cases and 6.7 million cancer-related deaths), 2008 (12.7 million cancer cases and 7.6 million cancer-related deaths), and 2012 (14.1 million cancer cases and 8.2 million cancer-related deaths) (1-4). On the other hand, the number of cancer-related deaths in Japan was about 380,000 in 2019 (in the order of

This article is freely accessible online.

Correspondence to: Hiroki Nishikawa, MD, Ph.D., the Second Department of Internal Medicine, Osaka Medical and Pharmaceutical University, 2-7, Daigakucho, Takatsukishi, Osaka, 569-8686, Japan. Tel: +81 726831221, e-mail: nishikawa_6392_0207@yahoo.co.jp

Key Words: Obesity, liver carcinogenesis, Japan, NASH, mechanism, epidemiology, review. lung, colon, stomach, pancreas, and liver), and one in three Japanese people died from cancer. This is traditionally thought to be due to the aging of the Japanese population.

Lifestyle-related factors play a major role in the development of cancer (5). In particular, smoking, drinking, overeating, and lack of exercise are the most important risk factors for the development of cancer (5). In recent years, obesity has become widespread in the world and has attracted attention not only as a cause of diabetes mellitus (DM) and atherosclerotic diseases but also as a factor in carcinogenesis (6-10). Currently, there are about 2.2 billion people in the world with a body mass index (BMI) over $25 \mathrm{~kg} / \mathrm{m}^{2}$, which means that about one in three people has a BMI over $25 \mathrm{~kg} / \mathrm{m}^{2}$ (11). It is also estimated that 4 million people die annually from obesity-related diseases, with more people dying from obesity than from malnutrition (12). In developed countries such as Europe and the United States, lifestyle-related cancers such as lung cancer, colon cancer, prostate cancer, and breast cancer are common, while in developing countries, cancers related to viral or bacterial infection, such as gastric cancer, hepatocellular carcinoma (HCC), and cervical cancer, are more common (12). In Japan, the number of obesity-related malignancies such as colorectal cancer, breast cancer, and prostate cancer has been increasing with the westernization of lifestyle, especially diet $(13,14)$. The recent increase in obesity in Japan suggests that obesity will become one of the major risk factors of cancer in Japan in the future.

While a research group at the University of North Carolina in the United States reported that obese people with a BMI of $30 \mathrm{~kg} / \mathrm{m}^{2}$ or more had a $46 \%$ increased risk of COVID-19 incidence, a $113 \%$ increased risk of requiring hospitalization, a $74 \%$ increased risk of being treated in an intensive care unit, and a $48 \%$ increased risk of dying from COVID-19, compared to those who were not obese (15). In addition, liver function in patients with nonalcoholic steatohepatitis (NASH) can deteriorate during the COVID-19 pandemic $(16,17)$. Thus, 
obesity is also an important social health problem in the COVID-19 pandemic. One of major concerns is that COVID19 vaccines may have decreased efficacy for persons with obesity compared to those with non-obesity (15).

Nonalcoholic fatty liver disease (NAFLD), which is commonly seen in obese patients, is currently the most frequent liver disease in developed countries, and it is estimated that there are more than 10 million NAFLD patients in Japan (18). NAFLD is classified into simple fatty liver and $\mathrm{NASH}$, and $10-20 \%$ of NASH patients will progress to cirrhosis and 2-3\% of them will develop HCC per year (18). Our national multicenter study of more than 20,000 cases on the etiology of HCC has shown a clear decrease in hepatitis virus-related $\mathrm{HCC}$ (from $85.3 \%$ to $64.4 \%$ in about 10 years) and a clear increase in non-B non-C HCC including NASHrelated HCC (prevalence of NASH-related HCC increased from $1.5 \%$ to $7.5 \%$ in about 10 years) (19). It is expected that a significant number of cases of burn-out NASH are included in cases of HCC with unknown etiology. There is also a clear trend towards an increase in non-viral causes of cirrhosis, including NASH (20). These epidemiological facts indicate that obesity is also an important factor in HCC. Koike et al. named the type of lifestyle-related HCC as metabolismassociated liver cancer (MALC) $(21,22)$. Research interest in MALC has been increasing in recent years. In this review, we will comprehensively summarize the relationship between obesity and HCC in Japan.

\section{Epidemiology of Obesity and Genetic Background in Japanese People}

The Japan Society for the Study of Obesity (JASSO) defines a BMI of $22 \mathrm{~kg} / \mathrm{m}^{2}$ as the appropriate weight (standard weight) that is statistically the least susceptible to disease. For Japanese people, JASSO defines a BMI of $25 \mathrm{~kg} / \mathrm{m}^{2}$ or higher as obesity because it increases the risk of developing complications such as glucose intolerance, dyslipidemia, and hypertension (WHO defines obesity as $30 \mathrm{~kg} / \mathrm{m}^{2}$ or higher). A BMI below $18.5 \mathrm{~kg} / \mathrm{m}^{2}$ is defined as underweight. In the last 20 years, the average BMI of Japanese men has increased from $23 \mathrm{~kg} / \mathrm{m}^{2}$ to $24 \mathrm{~kg} / \mathrm{m}^{2}$, while that of women has remained around $22 \mathrm{~kg} / \mathrm{m}^{2}$. In our analysis of 631 Japanese cases of chronic liver disease (CLD, from 2014 to 2020, median age $=65$ years, 309 males, 226 liver cirrhosis cases), the mean BMI of 309 men was $24.0 \mathrm{~kg} / \mathrm{m}^{2}$ [107 (34.6\%) cases with BMI $>25 \mathrm{~kg} / \mathrm{m}^{2}$ and $15(4.9 \%)$ cases with BMI $<18.5$ $\mathrm{kg} / \mathrm{m}^{2}$ ] , and the mean BMI of 322 women was $23.1 \mathrm{~kg} / \mathrm{m} 2$ [88 $(27.3 \%)$ cases with BMI $>25 \mathrm{~kg} / \mathrm{m}^{2}$ and $32(9.9 \%)$ cases with BMI $<18.5 \mathrm{~kg} / \mathrm{m}^{2}$ ]. The BMI of female CLD patients tends to be higher than the average Japanese BMI. The distribution of our CLD patients according to BMI is shown in Figure 1.

According to 2013 data, Japan has the lowest rate of obesity with a BMI of $30 \mathrm{~kg} / \mathrm{m}^{2}$ or more among developed countries $(<5 \%)$, and the United States has the highest rate (about 35\%), but in our study of liver disease, the rate of obesity with a BMI of $30 \mathrm{~kg} / \mathrm{m}^{2}$ or more was $7.1 \%(45 / 631$ cases), and thus CLD patients tend to be rather overnourished than the average Japanese people. On the other hand, the metabolic syndrome is defined as visceral obesity (visceral and abdominal obesity) with two or more symptoms of hyperglycemia, hypertension, and dyslipidemia (23), and JASSO defined "visceral obesity" as a visceral fat area (VFA) of $100 \mathrm{~cm}^{2}$ or more, but it should be noted that visceral obesity and BMI are not always correlated. BMI can be affected by not only fat mass but skeletal muscle mass and bone mass.

Obesity genes are associated with energy metabolism (2426). To date, more than 50 obesity-related genes have been identified, and the relationship between obesity and genetic variations such as the Adrenoceptor Beta 3 (ADRB3), uncoupling protein 1 (UCP1), and the Adrenoceptor Beta 2 (ADRB2) has been clarified (24-26). The ADRB3 gene is expressed in both brown and white adipose tissues, and is involved in the regulation of energy production in brown adipose tissue and lipolysis in white adipose tissue $(27,28)$. In 1995, the Trp64Arg polymorphism in the ADRB3 gene was reported to be involved in visceral obesity, insulin resistance, and early onset of type $2 \mathrm{DM}$, and a recent metaanalysis confirmed these associations (28). Individuals with the Trp64Arg mutation have a lower basal metabolic rate (BMR) and are therefore more resistant to starvation. The low BMR also means that once obese, weight loss is difficult (29). One in three Japanese people has the Trp64Arg mutation. It is estimated that the Trp64Arg mutation increases the susceptibility to NASH by 2.4-fold, and half of all NASH cases in Japan have the Trp64Arg mutation (30). Like ADRB3, individuals with mutations in UCP1 have a lower BMR due to reduced function of energy-burning brown adipose cells. Approximately one in four Japanese people carry a mutated gene in UCP1 (31). The ADRB2 gene is mainly expressed in the heart, bronchial smooth muscle, and prostate, but is also present in adipose tissue and involved in lipolysis (32). A Japanese research group reported that about $16 \%$ of Japanese people have the Arg16Gly polymorphism of the ADRB2 gene, and after diet and exercise therapy, the resting metabolic rate of the those carrying this $A D R B 2$ polymorphism becomes significantly higher than that of non-ADRB2 holders, and thus those that carry the $A D R B 2$ polymorphism tend to lose weight (33-35).

\section{Obesity as a Risk Factor for HCC}

Large-scale clinical epidemiological studies have shown that obesity can be a risk factor for cancer incidence $(36,37)$. In a 16-year prospective follow-up of 900,000 people in the United States, the risk ratio of HCC-related death among 
A

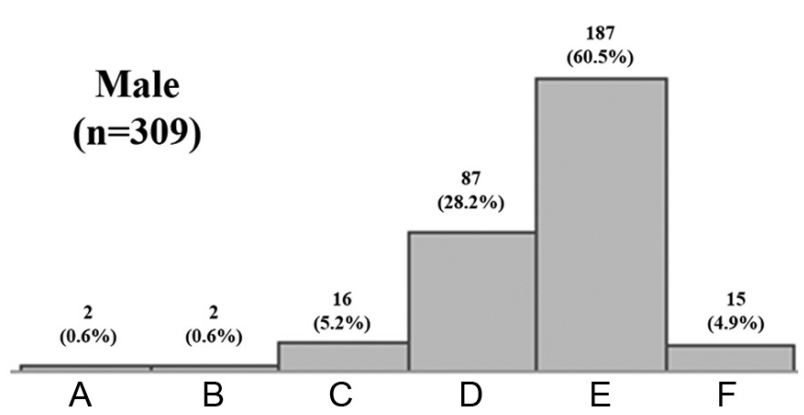

B

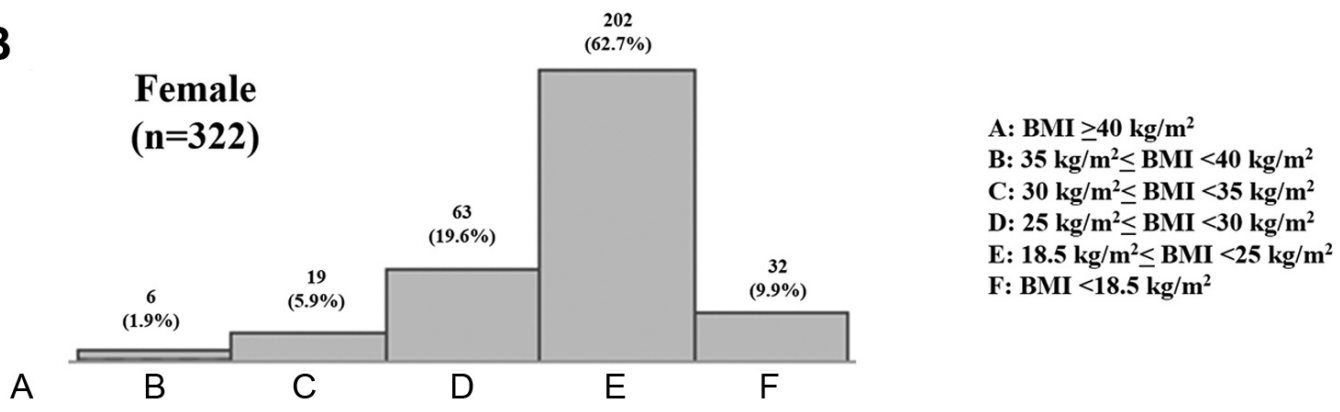

Figure 1. The distribution of patients with chronic liver disease according to body mass index [BMI, 309 men (A) and 322 women (B)].

obese people with a $\mathrm{BMI} \geq 35 \mathrm{~kg} / \mathrm{m}^{2}$ was 4.52 for men and 1.68 for women (36). In a Muto and colleague's study of 622 Japanese patients with decompensated LC, risk factors for hepatocarcinogenesis were male, DM, higher BMI, alphafetoprotein $\geq 20 \mathrm{ng} / \mathrm{ml}$, and lower serum albumin levels (38). Increased BMI in cirrhotic patients has also been associated with exacerbation of gastroesophageal varices, which is often complicated with cirrhosis and HCC (39).

Adipose tissue is considered to be the largest endocrine tissue in the human body, and secretes many adipocytokines including adiponectin (40). In particular, the increased secretion of TNF$\alpha$, decreased secretion of adiponectin, and increased secretion of leptin are associated with visceral fat accumulation and can cause insulin resistance (40). At the same time, compensatory hyperinsulinemia may occur. The mechanism of carcinogenesis in obesity lies in insulin resistance and its associated hyperinsulinemia. Insulin is known to 1) activate insulin receptor substrate-1 (IRS-1), 2) decrease the synthesis of insulin-like growth factor-1 (IGF-1) binding proteins (IGF-BPs) such as IGF-BP1 and IGF-BP2 in the liver, and 3) increase the amount of active free IGF-1 (41). IGF-1 influences HCC proliferation and progression through anti-apoptosis, increased angiogenesis via the production of vascular endothelial growth factor, and enhanced cell proliferative activity (42). Inflammatory cytokines such as TNF- $\alpha$ and IL- 6 have been suggested to promote hepatocarcinogenesis (43). IL-6 exerts its effects on cell proliferation and anti-apoptosis through activation of STAT3, whereas TNF $\alpha$ activates c-Jun-NH2-terminal kinase-
1 (JNK-1), nuclear factor-kappaB (NFkB), mammalian target of rapamycin (mTOR), extracellular signal-regulated kinase (ERK), etc., which have carcinogenic effects (43). In particular, it is well known that alterations in the PI3K/Akt/mTOR pathway are involved in oncogenic processes such as tumor angiogenesis and cancer-associated inflammation (44). Genetic instability caused by oxidative stress-induced DNA damage may lead to carcinogenesis, and iron overload may contribute to oxidative stress-induced DNA. Endoplasmic reticulum stress promotes hepatocarcinogenesis in cooperation with inflammatory cytokines such as TNF $\alpha$ (45).

Autophagy has attracted much attention in basic research as an intracellular mechanism that degrades its own intracellular tissues and provides energy during starvation, and has been shown to be impaired in NASH patients (46). A decline in autophagy in liver sinusoidal endothelial cells can lead to insulin resistance and NASH. Dysfunction in endothelial autophagy promotes liver inflammation and liver fibrosis in the early stages of NASH (46). This autophagy dysfunction is also involved in liver carcinogenesis (47).

\section{NAFLD, NASH and HCC}

Many diseases, such as collagen diseases, are known to be caused by environmental factors that induce the disease in addition to the host's susceptibility to the disease. Lifestylerelated diseases, which have been on the rise in recent years, are no exception to this rule. Obesity is the most well- 
known factor triggering NAFLD, and most people with a BMI of $30 \mathrm{~kg} / \mathrm{m}^{2}$ or more develop NAFLD (48). The relative risk of developing $\mathrm{NASH}$ in highly obese individuals is extremely high, 30 to 50 times higher than in non-obese individuals (BMI $<25 \mathrm{~kg} / \mathrm{m}^{2}$ ) (49). On the other hand, numerous clinical data have been accumulated on NAFLD in non-obese individuals. A recent meta-analysis reported that $40 \%$ of patients with NAFLD are lean or nonobese, and progression of liver disease and development of cardiovascular diseases are seen in a significant number of non-obese NAFLD cases in the long-term course (50).

Two factors are involved in the pathogenesis of NAFLD: genetic factors and environmental factors, such as weight gain (51). Patatin-like phospholipase domain containing 3 (PNPLA3) gene was reported as a susceptibility gene involved in the development of NAFLD $(52,53)$. PNPLA3 is localized in lipid droplet membranes and involved in lipid metabolism by promoting trans-amylase and lipase activities, and therefore gene polymorphisms in this region are involved in abnormal lipid metabolism. The PNPLA3 gene can be divided into CC, CG, and GG types, and people with $\mathrm{G}$ are more likely to develop NAFLD (GG type >CG type $>\mathrm{CC}$ type in the risk of NAFLD) $(52,53)$. It is known that Japanese people have a high percentage of fatty liver even though they are not as fatty as Westerners. A comparison of the percentage of Japanese and British people with the PNPLA3 gene GG type showed that $21 \%$ of Japanese have the GG type, compared to $5 \%$ of British people $(51,54,55)$. Because of the high percentage of Japanese with the PNPLA3 gene GG type, which tends to store fat in the liver, it is thought that Japanese are more likely to develop NASH even if they are not obese. In Japanese NAFLD patients, advanced fibrosis and PNPLA3 GG genotype were independent risk factors for $\mathrm{HCC}$ incidence (54).

Kawaguchi et al. identified four disease susceptibility genes (DYSF, GCKR, PNPLA3, and GATAD2A) in a whole genome association analysis of 902 Japanese NAFLD patients (56). They reported that GCKR is associated with simple fatty liver, GATAD2A with NASH, DYSF with NASH-related HCC, and PNPLA3 with all of them. By combining these genes, the hazard ratio (HR) for those at the highest risk of developing NAFLD (those with more risk alleles) was 5.0-fold higher than that for those at the lowest risk. They also reported that in patients with more risk alleles, the HR of developing NASH from NAFLD was 4.4 times higher and that of developing NASH-related HCC from NASH was 15.9 times higher (56). Usefulness of the polygenic risk scores (combination of variants in PNPLA3TM6SF2-GCKR-MBOAT7) for the stratification of HCC incidence in NAFLD patients has also been reported (57). Another study reported that a genetic risk score (combined PNPLA3, TM6SF2, and HSD17B13 variants) for fatty liver disease is associated with up to 12 times the risk of cirrhosis and up to 29 times the risk of HCC incidence in the general population (58). While patients with hepatitis $\mathrm{C}$ virus (HCV)-related cirrhosis are at risk of developing obesity after sustained virological response (SVR) (59). Liver steatosis can be an adverse predictor after SVR for HCV (60). PNPLA3 and HLA-DQB1 polymorphisms can be also linked to HCC incidence after SVR for HCV (61).

\section{DM and HCC}

The liver, along with skeletal muscle and adipose tissue, is a major target organ of insulin and an important organ responsible for the homeostasis of glucose metabolism (62). The prevalence of DM in Japan continues to rise. The possible association between DM and major chronic diseases, including cancer, has been emphasized from basic, clinical, and preventive medicine perspectives (63-66). The relationship between DM and HCC can be explained by multiple biological mechanisms, including the suppression of IGF-BP1 production due to excessive insulin secretion and increased oxidative stress due to hyperglycemia (22). In Japan, HCC accounts for more than $90 \%$ of primary liver cancers. Diabetic patients have a 23 times increased risk of HCC compared to those without diabetes, based on the results of several meta-analyses (67-71). The presence of DM in patients with HCC can be a poor prognostic factor (72). DM is associated with cisplatin sensitivity of HCC cells and invasive ability of HCC cells, and has been reported to interfere with the chemotherapeutic effects for HCC (73). The usefulness of the FIB-4 index (liver fibrosis marker) in liver carcinogenesis in diabetic patients (cut-off value=3.61) has also been reported (74).

It has been reported that insulin and sulfonylurea promote hepatocarcinogenesis, while insulin resistance ameliorators such as metformin inhibit carcinogenesis (75). Metformin is a diabetic drug that improves insulin resistance via activation of AMP kinase (AMPK) in hepatocytes (76). Metformin has been shown to have a variety of anti-tumor effects, including direct inhibition of cell proliferation and induction of apoptosis in liver cancer cells (76-78). Therefore, metformin may be useful in the management of diabetic CLD patients, but care should be taken to avoid lactic acidosis. Kawaguchi et al. reported that $66.5 \%$ of 478 diabetic CLD patients were treated with some kind of antidiabetic drug, and the frequency of prescriptions by drug type was $39.0 \%$ for dipeptidyopeptidase 4 (DPP4) inhibitors, $25.5 \%$ for insulin, $25.5 \%$ for sulfonylureas, and $17 \%$ for metformin (79). Furthermore, favorable effects of dietary habits on liver carcinogenesis have also been reported. A previous meta-analysis also reported that the habit of coffee consumption suppresses HCC development (80). People who drink three or more cups of coffee a day have a $40 \%$ lower risk of HCC incidence compared to those who do not (80). It is thought that coffee may prevent HCC incidence by reducing liver inflammation (81). 


\section{Obesity, Gut Microbiota and Hepatocarcinogenesis}

In the human gastrointestinal tract, there are 500 to 1,000 species of intestinal bacteria, numbering more than 100 trillion, which live in symbiosis with the host by metabolizing substances that the host cannot metabolize and by regulating the host's immune system (82). Changes in the gut microbiota (i.e., dysbiosis), such as an increase in ammonia-producing gram-positive bacteria, have been noted in obese individuals (83). Hyperammonemia and subsequent hypermyostatinemia can induce muscle protein breakdown and can be associated with fat accumulation in the liver (84, $85)$. Serum myostatin levels have a strong effect on muscle protein breakdown and had a positive correlation with serum ammonia levels in our previous study (84). In obesity, mild inflammatory cell infiltration occurs in white adipose tissue, and chronic inflammation is thought to induce insulin resistance and glucose intolerance. Fatty acids act as ligands for TLR4 to trigger chronic inflammation, and the involvement of endotoxins from gut microbiota in chronic inflammation has attracted attention (86). Lipopolysaccharide (LPS), an endotoxin, is derived from intestinal bacteria, and high-fat-fed mice have altered intestinal microflora and increased LPS levels in their blood (metabolic endotoxemia) (87). LPS can be associated with the progression of hepatic steatosis in the development of NAFLD in rats (88). Administration of antibiotics to highfat-fed mice reduces the inflammatory response in the intestinal tract, alleviates metabolic endotoxemia, and improves obesity, insulin resistance, and adipose tissue inflammation (87). Conversely, sustained administration of small amounts of LPS to mice causes obesity, insulin resistance, and glucose intolerance similar to those in highfat-fed mice $(89,90)$.

The increase in deoxycholic acid, a secondary bile acid associated with changes in the intestinal microbiota, can induce cellular senescence in hepatic stellate cells (irreversible cessation of cell proliferation induced by strong carcinogenic stress such as DNA damage in normal cells) (91). The senescent cells secrete various proteins that promote inflammation and carcinogenesis, such as inflammatory cytokines, chemokines, and extracellular matrix-degrading enzymes, leading to a phenomenon called senescence associated secretory phenotype, which leads to carcinogenesis (91). Unlike apoptosis, senescent cells do not die immediately but survive for a long time.

\section{Sarcopenic Obesity and HCC}

The term "primary sarcopenia" refers to a condition in which skeletal muscle mass, strength, or physical function is reduced due to aging, and the term "secondary sarcopenia" refers to a condition in which skeletal muscle mass, strength, or physical function is reduced due to an underlying disease. Cirrhosis, which is often associated with HCC, tends to be associated with secondary sarcopenia (92). Secondary sarcopenia in cirrhosis can be regulated by myostatin in skeletal muscle due to decreased ammonia clearance (84). Sarcopenic obesity, which is a combination of sarcopenia and obesity, is not a mere combination of conditions, but rather a stronger manifestation of metabolic abnormalities and functional disorders (62). It has been shown that obesity and insulin resistance may be a risk factor for sarcopenia, and sarcopenic obesity is a condition in which skeletal muscle is replaced by fat (93). Sarcopenic obesity patients are more likely to suffer from functional decline, falls, fractures, and death than those with sarcopenia alone or obesity alone (94-96). Sarcopenic obesity leads to fat accumulation in muscles and increased insulin resistance (62). It is unclear whether sarcopenia obesity is more strongly associated with liver carcinogenesis than obesity alone.

Sarcopenic obesity is an important condition in HCC. Kobayashi et al. classified 465 Japanese HCC patients who underwent hepatectomy into four groups according to sarcopenia and obesity: non-sarcopenic non-obese group, non-sarcopenic obese group, sarcopenic non-obese group, and sarcopenic obesity group, and examined the postoperative and recurrence-free survival rates among the four groups (97). Sarcopenia was defined as a skeletal muscle index (SMI) of $<40.31 \mathrm{~cm}^{2} / \mathrm{m}^{2}$ in male patients on computed tomography (CT) and a SMI of $<30.88 \mathrm{~cm}^{2} / \mathrm{m}^{2}$ in female patients on CT. Obesity was defined as a VFA of $\geq 100 \mathrm{~cm}^{2}$ in both sexes, and 250 patients $(53.8 \%)$ had complications of obesity. In the multivariate analysis of prognostic factors, poorly differentiated HCC $(\mathrm{HR}=1.945$, $p=0.011)$, TNM stage III or higher $(\mathrm{HR}=2.267, p=0.003)$, serious complications $(\mathrm{HR}=1.906, p=0.016)$, and sarcopenic obesity $(\mathrm{HR}=2.504, p=0.005)$ were independent risk factors for overall survival. Sarcopenic obesity $(\mathrm{HR}=2.504, p=0.005)$ and TNM stage III or higher $(\mathrm{HR}=2.972, p<0.001)$ were independent risk factors for postoperative HCC recurrence (98). In living donor liver transplantation for $\mathrm{HCC}$, the presence of preoperative sarcopenic obesity is a contributing factor to $\mathrm{HCC}$ recurrence and survival (98). Sarcopenic obesity may be superior to sarcopenia as a predictive factor in $\mathrm{HCC}$ patients undergoing hepatic resection, and it should be a priority for researchers and clinicians (99). Sarcopenic obesity assessment should be incorporated for HCC patients. In addition, a worldwide unified consensus for the assessment of sarcopenic obesity should be established. Definition of sarcopenic obesity varies among studies (62). Schematic explanation between obesity, insulin resistance, gut microbiota, sarcopenic obesity, and liver carcinogenesis is shown in Figure 2. 


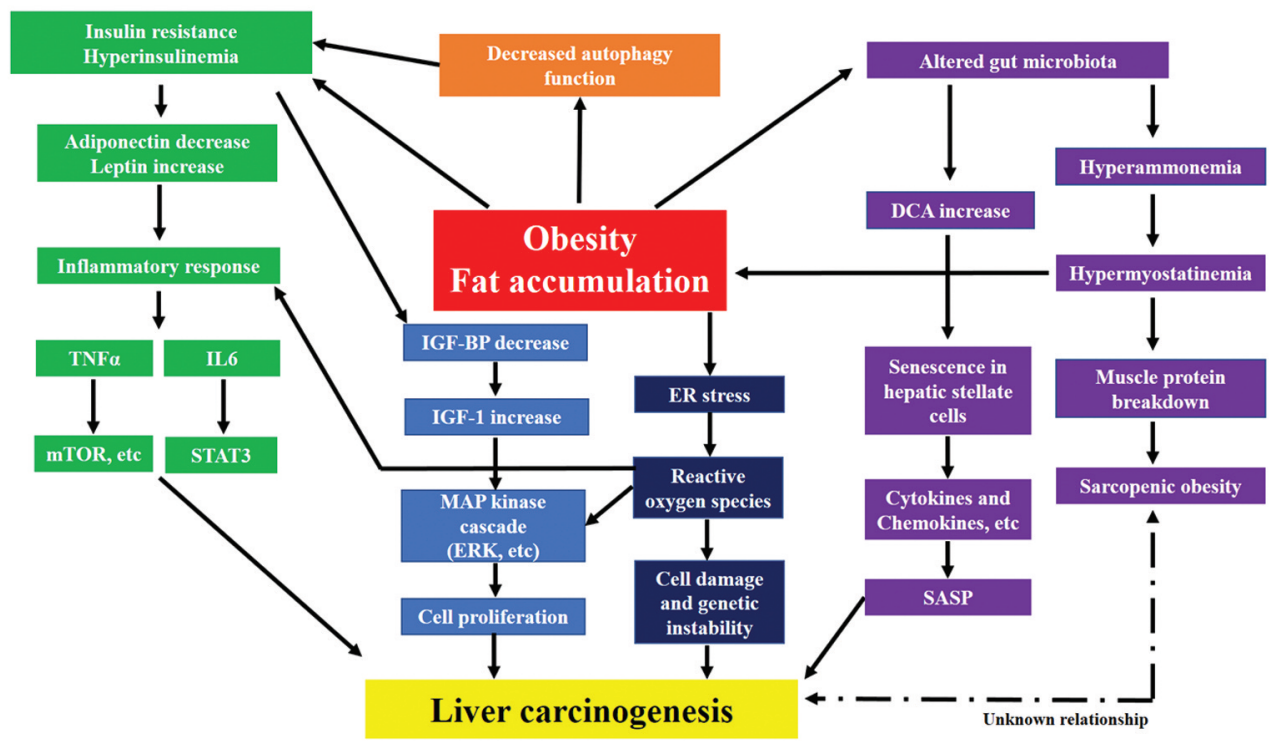

Figure 2. Schematic description of the interactions between obesity, insulin resistance, gut microbiota, sarcopenic obesity, and liver carcinogenesis. mTOR: Mammalian target of rapamycin; IGF: insulin-like growth factor; IGF-BP: insulin-like growth factor binding protein; SASP: senescence associated secretory phenotype; ERK: extracellular signal-regulated kinase; ER: endoplasmic reticulum; DCA: deoxycholic acid.

\section{Obesity Control as a Cancer Prevention Mechanism}

It is internationally recognized that smoking cessation is the first and most important factor in cancer prevention, but that obesity control comes next. The results of a pooled analysis of seven cohort studies in Japan showed that the risk of cancer was low in men with a BMI of $21.0-26.9 \mathrm{~kg} / \mathrm{m}^{2}$ and in women with a BMI of $21.0-24.9 \mathrm{~kg} / \mathrm{m}^{2}$ (100). In addition, a research group at the National Cancer Center in Japan examined previous studies on Japanese people and identified five factors that are important for the prevention of cancer in Japanese people: smoking cessation, sobriety, diet, physical activity, and maintenance of appropriate weight (101). It was estimated that people who practice these five healthy habits have a $43 \%$ lower risk of cancer incidence in men and a $37 \%$ lower risk in women compared to those who practice 0 or 1 (101). For both men and women, the higher the amount of physical activity, the lower the risk of developing any type of cancer. In particular, the risk reduction was more clearly seen in the elderly and in those who had more opportunities to play sports or exercise on holidays. According to cancer primary site, the risk of colon, liver, and pancreatic cancer in men, and gastric cancer in women was lowered in those with higher levels of physical activity (102).

Bariatric surgery is a procedure used to treat severe obesity and is effective and safe for highly obese individuals (103). In a recent meta-analysis, bariatric surgery was shown to reduce the overall cancer incidence and obesity-related cancer incidence (104). Bariatric surgery has been reported to significantly reduce the incidence of $\mathrm{HCC}$ through the improvement of NASH $(105,106)$. However, bariatric surgery is not so common in Japan.

\section{Closing Remarks}

Recent progress in molecular biology research has gradually elucidated the molecular mechanisms of obesity and hepatocarcinogenesis, and clinical data are gradually being accumulated. In this article, obesity and hepatocarcinogenesis were comprehensively reviewed by introducing representative Japanese data in terms of 1) clinical epidemiology, 2) genetic background, 3) mechanism of carcinogenesis, 4) NAFLD, NASH and hepatocarcinogenesis, 5) DM and hepato-carcinogenesis, 6) intestinal microbiota and hepatocarcino-genesis, 7) sarcopenic obesity in HCC patients, and 8) obesity control as a cancer prevention. As the number of obese patients increases internationally, including in Japan, the relationship between obesity and carcinogenesis has become an important issue that cannot be overlooked, and appropriate intervention for obese patients is required. Further evidence is expected to be accumulated in the future.

\section{Conflicts of Interest}

The Authors have no conflicts of interest to declare in relation to this study. 


\section{Authors' Contributions}

Writing the article: H.N.; Editing the article: S.F., A.A., S.N., K.H.; Final approval: all Authors.

\section{References}

1 Bray F, Ferlay J, Soerjomataram I, Siegel RL, Torre LA and Jemal A: Global cancer statistics 2018: GLOBOCAN estimates of incidence and mortality worldwide for 36 cancers in 185 countries. CA Cancer J Clin 68(6): 394-424, 2018. PMID: 30207593. DOI: $10.3322 /$ caac. 21492

2 Parkin DM, Bray F, Ferlay $\mathrm{J}$ and Pisani P: Global cancer statistics, 2002. CA Cancer J Clin 55(2): 74-108, 2005. PMID: 15761078. DOI: 10.3322/canjclin.55.2.74

3 Jemal A, Bray F, Center MM, Ferlay J, Ward E and Forman D: Global cancer statistics. CA Cancer J Clin 61(2): 69-90, 2011. PMID: 21296855. DOI: 10.3322/caac.20107

4 Torre LA, Bray F, Siegel RL, Ferlay J, Lortet-Tieulent J and Jemal A: Global cancer statistics, 2012. CA Cancer J Clin 65(2): 87-108, 2015. PMID: 25651787. DOI: 10.3322/caac.21262

5 Grosso G, Bella F, Godos J, Sciacca S, Del Rio D, Ray S, Galvano F and Giovannucci EL: Possible role of diet in cancer: systematic review and multiple meta-analyses of dietary patterns, lifestyle factors, and cancer risk. Nutr Rev 75(6): 405419, 2017. PMID: 28969358. DOI: 10.1093/nutrit/nux012

6 Cheng F, Carroll L, Joglekar MV, Januszewski AS, Wong KK, Hardikar AA, Jenkins AJ and Ma RCW: Diabetes, metabolic disease, and telomere length. Lancet Diabetes Endocrinol 9(2): 117-126, 2021. PMID: 33248477. DOI: 10.1016/S22138587(20)30365-X

7 The Lancet Diabetes Endocrinology: The obesity-cancer link: of increasing concern. Lancet Diabetes Endocrinol 8(3): 175, 2020. PMID: 32032541. DOI: 10.1016/S2213-8587(20)30031-0

8 Sung H, Siegel RL, Rosenberg PS and Jemal A: Emerging cancer trends among young adults in the USA: analysis of a population-based cancer registry. Lancet Public Health 4(3): e137-e147, 2019. PMID: 30733056. DOI: 10.1016/S24682667(18)30267-6

9 Liu PH, Wu K, Ng K, Zauber AG, Nguyen LH, Song M, He X, Fuchs CS, Ogino S, Willett WC, Chan AT, Giovannucci EL and Cao Y: Association of obesity with risk of early-onset colorectal cancer among women. JAMA Oncol 5(1): 37-44, 2019. PMID 30326010. DOI: 10.1001/jamaoncol.2018.4280

10 Koroukian SM, Dong W and Berger NA: Changes in age distribution of obesity-associated cancers. JAMA Netw Open 2(8): e199261, 2019. PMID: 31411715. DOI: 10.1001/jamanet workopen.2019.9261

11 Dai $\mathrm{H}$, Alsalhe TA, Chalghaf N, Riccò M, Bragazzi NL and Wu $\mathrm{J}$ : The global burden of disease attributable to high body mass index in 195 countries and territories, 1990-2017: An analysis of the Global Burden of Disease Study. PLoS Med 17(7): e1003198, 2020. PMID: 32722671. DOI: 10.1371/journal.pmed.1003198

12 Vineis P and Wild CP: Global cancer patterns: causes and prevention. Lancet 383(9916): 549-557, 2014. PMID: 24351322. DOI: $10.1016 / \mathrm{S} 0140-6736(13) 62224-2$

13 Wakamatsu M, Sugawara Y, Zhang S, Tanji F, Tomata Y and Tsuji I: Weight change since age 20 and incident risk of obesityrelated cancer in Japan: a pooled analysis of the Miyagi Cohort
Study and the Ohsaki Cohort Study. Int J Cancer 144(5): 967980, 2019. PMID: 29992563. DOI: 10.1002/ijc.31743

14 Nanri A, Mizoue T, Takahashi Y, Noda M, Inoue M, Tsugane S and Japan Public Health Center-based Prospective Study Group: Weight change and all-cause, cancer and cardiovascular disease mortality in Japanese men and women: the Japan Public Health Center-Based Prospective Study. Int J Obes (Lond) 34(2): 348356, 2010. PMID: 19918251. DOI: 10.1038/ijo.2009.234

15 Popkin BM, Du S, Green WD, Beck MA, Algaith T, Herbst CH, Alsukait RF, Alluhidan M, Alazemi N and Shekar M: Individuals with obesity and COVID-19: A global perspective on the epidemiology and biological relationships. Obes Rev 21(11): e13128, 2020. PMID: 32845580. DOI: 10.1111/obr.13128

16 Asai A, Yasuoka H, Matsui M, Okamoto N, Fukunishi S and Higuchi K: Exacerbation of liver dysfunction in non-alcoholic steatohepatitis patients during the coronavirus disease 2019 (COVID-19) pandemic. Journal of Clinical Biochemistry and Nutrition, 2020. DOI: 10.3164/jcbn.20-136

17 Portincasa P, Krawczyk M, Smyk W, Lammert F and Di Ciaula A: COVID-19 and non-alcoholic fatty liver disease: Two intersecting pandemics. Eur J Clin Invest 50(10): e13338, 2020. PMID: 32589264. DOI: 10.1111/eci.13338

18 Ito T, Ishigami M, Zou B, Tanaka T, Takahashi H, Kurosaki M, Maeda M, Thin KN, Tanaka K, Takahashi Y, Itoh Y, Oniki K, Seko Y, Saruwatari J, Kawanaka M, Atsukawa M, Hyogo H, Ono M, Ogawa E, Barnett SD, Stave CD, Cheung RC, Fujishiro M, Eguchi Y, Toyoda $\mathrm{H}$ and Nguyen $\mathrm{MH}$ : The epidemiology of NAFLD and lean NAFLD in Japan: a meta-analysis with individual and forecasting analysis, 1995-2040. Hepatol Int, 2021. PMID: 33580453. DOI: 10.1007/s12072-021-10143-4

19 Enomoto H, Ueno Y, Hiasa Y, Nishikawa H, Hige S, Takikawa Y, Taniai M, Ishikawa T, Yasui K, Takaki A, Takaguchi K, Ido A, Kurosaki M, Kanto T, Nishiguchi S and Japan Etiology of Liver Cirrhosis Study Group in the 54th Annual Meeting of JSH: The transition in the etiologies of hepatocellular carcinoma-complicated liver cirrhosis in a nationwide survey of Japan. J Gastroenterol 56(2): 158-167, 2021. PMID: 33219410. DOI: $10.1007 / \mathrm{s} 00535-020-01748-\mathrm{x}$

20 Enomoto H, Ueno Y, Hiasa Y, Nishikawa H, Hige S, Takikawa Y, Taniai M, Ishikawa T, Yasui K, Takaki A, Takaguchi K, Ido A, Kurosaki M, Kanto T, Nishiguchi S and Japan Etiology of Liver Cirrhosis Study Group in the 54th Annual Meeting of JSH: Transition in the etiology of liver cirrhosis in Japan: a nationwide survey. J Gastroenterol 55(3): 353-362, 2020. PMID: 31768801. DOI: 10.1007/s00535-019-01645-y

21 Tateishi R, Uchino K, Fujiwara N, Takehara T, Okanoue T, Seike M, Yoshiji H, Yatsuhashi H, Shimizu M, Torimura T, Moriyama M, Sakaida I, Okada H, Chiba T, Chuma M, Nakao K, Isomoto H, Sasaki Y, Kaneko S, Masaki T, Chayama K and Koike K: A nationwide survey on non-B, non-C hepatocellular carcinoma in Japan: 2011-2015 update. J Gastroenterol 54(4): 367-376, 2019. PMID: 30498904. DOI: 10.1007/s00535-018-1532-5

22 Llovet JM, Kelley RK, Villanueva A, Singal AG, Pikarsky E, Roayaie S, Lencioni R, Koike K, Zucman-Rossi J and Finn RS: Hepatocellular carcinoma. Nat Rev Dis Primers 7(1): 6, 2021. PMID: 33479224. DOI: 10.1038/s41572-020-00240-3

23 Yamagishi $\mathrm{K}$ and Iso $\mathrm{H}$ : The criteria for metabolic syndrome and the national health screening and education system in Japan. Epidemiol Health 39: e2017003, 2017. PMID: 28092931. DOI: 10.4178/epih.e2017003 
24 Landrier JF, Derghal A and Mounien L: MicroRNAs in obesity and related metabolic disorders. Cells 8(8): 859, 2019. PMID: 31404962. DOI: 10.3390/cells8080859

25 Iacomino G and Siani A: Role of microRNAs in obesity and obesity-related diseases. Genes Nutr 12: 23, 2017. PMID: 28974990. DOI: 10.1186/s12263-017-0577-z

26 Crovesy L and Rosado EL: Interaction between genes involved in energy intake regulation and diet in obesity. Nutrition 67-68: 110547, 2019. PMID: 31472367. DOI: 10.1016/j.nut.2019.06.027

27 Fujisawa T, Ikegami H, Yamato E, Takekawa K, Nakagawa Y, Hamada Y, Oga T, Ueda H, Shintani M, Fukuda M and Ogihara T: Association of Trp64Arg mutation of the beta3-adrenergicreceptor with NIDDM and body weight gain. Diabetologia 39(3): 349-352, 1996. PMID: 8721782. DOI: 10.1007/BF00418352

28 Luo Z, Zhang T, Wang S, He Y, Ye Q and Cao W: The Trp64Arg polymorphism in $\beta 3$ adrenergic receptor (ADRB3) gene is associated with adipokines and plasma lipids: a systematic review, meta-analysis, and meta-regression. Lipids Health Dis 19(1): 99, 2020. PMID: 32430022. DOI: 10.1186/s12944-020-01290-y

29 Piétri-Rouxel F, St John Manning B, Gros J and Strosberg AD: The biochemical effect of the naturally occurring Trp64->Arg mutation on human beta3-adrenoceptor activity. Eur J Biochem 247(3): 1174-1179, 1997. PMID: 9288945. DOI: 10.1111/j.14321033.1997.01174.x

30 Nozaki Y, Saibara T, Nemoto Y, Ono M, Akisawa N, Iwasaki S, Hayashi Y, Hiroi M, Enzan H and Onishi S: Polymorphisms of interleukin-1 beta and beta 3-adrenergic receptor in Japanese patients with nonalcoholic steatohepatitis. Alcohol Clin Exp Res 28(s2): 106S-110S, 2004. PMID: 15318095. DOI: 10.1111/j.1530-0277.2004.tb03226.x

31 Ikeda K, Kang Q, Yoneshiro T, Camporez JP, Maki H, Homma M, Shinoda K, Chen Y, Lu X, Maretich P, Tajima K, Ajuwon KM, Soga T and Kajimura S: UCP1-independent signaling involving SERCA2b-mediated calcium cycling regulates beige fat thermogenesis and systemic glucose homeostasis. Nat Med 23(12): 1454-1465, 2017. PMID: 29131158. DOI: 10.1038/ $\mathrm{nm} .4429$

32 Tsunekawa K, Yanagawa Y, Aoki T, Morimura T, Araki O, Ogiwara T, Kawai Y, Mitani Y, Lezhava A, Yanagawa M, Hayashizaki $Y$ and Murakami M: Association between accumulation of visceral fat and the combination of $\beta 3$ adrenergic receptor Trp64Arg, $\beta 2$ adrenergic receptor Arg16Gly and uncoupling protein $1-3826 \mathrm{~A}>\mathrm{G}$ polymorphisms detected by Smart Amplification Process 2. Endocr J 58(12): 1079-1086, 2011. PMID: 21959333. DOI: 10.1507/endocrj.ej11-0148

33 Sakane N, Yoshida T, Umekawa T, Kogure A and Kondo M: Beta2-adrenoceptor gene polymorphism and obesity. Lancet 353(9168): 1976, 1999. PMID: 10371603. DOI: 10.1016/ S0140-6736(05)77192-0

34 Large V, Hellström L, Reynisdottir S, Lönnqvist F, Eriksson P, Lannfelt L and Arner P: Human beta-2 adrenoceptor gene polymorphisms are highly frequent in obesity and associate with altered adipocyte beta-2 adrenoceptor function. J Clin Invest 100(12): 3005-3013, 1997. PMID: 9399946. DOI: 10.1172/JCI119854

35 Meirhaeghe A, Luan J, Selberg-Franks P, Hennings S, Mitchell J, Halsall D, O'Rahilly S and Wareham NJ: The effect of the Gly16Arg polymorphism of the beta(2)-adrenergic receptor gene on plasma free fatty acid levels is modulated by physical activity. J Clin Endocrinol Metab 86(12): 5881-5887, 2001. PMID: 11739457. DOI: 10.1210/jcem.86.12.8103

36 Calle EE, Rodriguez C, Walker-Thurmond $\mathrm{K}$ and Thun MJ: Overweight, obesity, and mortality from cancer in a prospectively studied cohort of U.S. adults. N Engl J Med 348(17): 1625-1638, 2003. PMID: 12711737. DOI: 10.1056/NEJMoa021423

37 Bhaskaran K, Douglas I, Forbes H, dos-Santos-Silva I, Leon DA and Smeeth L: Body-mass index and risk of 22 specific cancers: a population-based cohort study of $5 \cdot 24$ million UK adults. Lancet 384(9945): 755-765, 2014. PMID: 25129328. DOI: $10.1016 / \mathrm{S} 0140-6736(14) 60892-8$

38 Muto Y, Sato S, Watanabe A, Moriwaki H, Suzuki K, Kato A, Kato M, Nakamura T, Higuchi K, Nishiguchi S, Kumada H, Ohashi Y and Long-Term Survival Study (LOTUS) Group: Overweight and obesity increase the risk for liver cancer in patients with liver cirrhosis and long-term oral supplementation with branched-chain amino acid granules inhibits liver carcinogenesis in heavier patients with liver cirrhosis. Hepatol Res 35(3): 204-214, 2006. PMID: 16737844. DOI: 10.1016/ j.hepres.2006.04.007

39 Enomoto H, Aizawa N, Ikeda N, Sakai Y, Takata R, Hasegawa K, Miyamoto Y, Inoue M, Nishimura T, Nakano C, Ishii N, Yuri Y, Yoh K, Ishii A, Takashima T, Nishikawa H, Iwata Y, Iijima $\mathrm{H}$ and Nishiguchi S: Association of the body mass index with the presence of gastroesophageal varices in compensated cirrhotic patients with hepatitis $\mathrm{C}$ viral infection. Ann Clin Lab Sci 48(6): 801-804, 2018. PMID: 30610054.

40 Matsuzawa Y: Establishment of a concept of visceral fat syndrome and discovery of adiponectin. Proc Jpn Acad Ser B Phys Biol Sci 86(2): 131-141, 2010. PMID: 20154470. DOI: 10.2183/pjab.86.131

41 Chettouh H, Lequoy M, Fartoux L, Vigouroux C and DesboisMouthon C: Hyperinsulinaemia and insulin signalling in the pathogenesis and the clinical course of hepatocellular carcinoma. Liver Int 35(10): 2203-2217, 2015. PMID: 26123841. DOI: 10.1111/liv.12903

42 Adamek A and Kasprzak A: Insulin-like growth factor (IGF) system in liver diseases. Int J Mol Sci 19(5): 1308, 2018. PMID: 29702590. DOI: 10.3390/ijms19051308

43 Park EJ, Lee JH, Yu GY, He G, Ali SR, Holzer RG, Osterreicher $\mathrm{CH}$, Takahashi $\mathrm{H}$ and Karin $\mathrm{M}$ : Dietary and genetic obesity promote liver inflammation and tumorigenesis by enhancing IL-6 and TNF expression. Cell 140(2): 197-208, 2010. PMID: 20141834. DOI: 10.1016/j.cell.2009.12.052

44 Popova NV and Jücker M: The role of mTOR signaling as a therapeutic target in cancer. Int J Mol Sci 22(4): 1743, 2021. PMID: 33572326. DOI: 10.3390/ijms22041743

45 Nakagawa H, Umemura A, Taniguchi K, Font-Burgada J, Dhar D, Ogata H, Zhong Z, Valasek MA, Seki E, Hidalgo J, Koike $\mathrm{K}$, Kaufman RJ and Karin M: ER stress cooperates with hypernutrition to trigger TNF-dependent spontaneous HCC development. Cancer Cell 26(3): 331-343, 2014. PMID: 25132496. DOI: 10.1016/j.ccr.2014.07.001

46 Hammoutene A, Biquard L, Lasselin J, Kheloufi M, Tanguy M, Vion AC, Mérian J, Colnot N, Loyer X, Tedgui A, Codogno P, Lotersztajn S, Paradis V, Boulanger CM and Rautou PE: A defect in endothelial autophagy occurs in patients with nonalcoholic steatohepatitis and promotes inflammation and fibrosis. J Hepatol 72(3): 528-538, 2020. PMID: 31726115. DOI: $10.1016 /$ j.jhep.2019.10.028 
47 Takamura A, Komatsu M, Hara T, Sakamoto A, Kishi C, Waguri S, Eishi Y, Hino O, Tanaka K and Mizushima N: Autophagydeficient mice develop multiple liver tumors. Genes Dev 25(8): 795-800, 2011. PMID: 21498569. DOI: 10.1101/gad.2016211

48 Milić S, Lulić D and Štimac D: Non-alcoholic fatty liver disease and obesity: biochemical, metabolic and clinical presentations. World J Gastroenterol 20(28): 9330-9337, 2014. PMID: 25071327. DOI: 10.3748/wjg.v20.i28.9330

49 Loomis AK, Kabadi S, Preiss D, Hyde C, Bonato V, St Louis M, Desai J, Gill JM, Welsh P, Waterworth D and Sattar N: Body mass index and risk of nonalcoholic fatty liver disease: two electronic health record prospective studies. J Clin Endocrinol Metab 101(3): 945-952, 2016. PMID: 26672639. DOI: 10.1210/jc.2015-3444

50 Ye Q, Zou B, Yeo YH, Li J, Huang DQ, Wu Y, Yang H, Liu C, Kam LY, Tan XXE, Chien N, Trinh S, Henry L, Stave CD, Hosaka T, Cheung RC and Nguyen MH: Global prevalence, incidence, and outcomes of non-obese or lean non-alcoholic fatty liver disease: a systematic review and meta-analysis. Lancet Gastroenterol Hepatol 5(8): 739-752, 2020. PMID: 32413340. DOI: 10.1016/S2468-1253(20)30077-7

51 Nishioji K, Mochizuki N, Kobayashi M, Kamaguchi M, Sumida Y, Nishimura T, Yamaguchi K, Kadotani $\mathrm{H}$ and Itoh Y: The impact of PNPLA3 rs738409 genetic polymorphism and weight gain $\geq 10 \mathrm{~kg}$ after age 20 on non-alcoholic fatty liver disease in non-obese Japanese individuals. PLoS One 10(10): e0140427, 2015. PMID: 26485523. DOI: 10.1371/journal.pone.0140427

52 Romeo S, Kozlitina J, Xing C, Pertsemlidis A, Cox D, Pennacchio LA, Boerwinkle E, Cohen JC and Hobbs HH: Genetic variation in PNPLA3 confers susceptibility to nonalcoholic fatty liver disease. Nat Genet 40(12): 1461-1465, 2008. PMID: 18820647. DOI: 10.1038/ng.257

53 Hotta K, Yoneda M, Hyogo H, Ochi H, Mizusawa S, Ueno T, Chayama K, Nakajima A, Nakao K and Sekine A: Association of the rs 738409 polymorphism in PNPLA3 with liver damage and the development of nonalcoholic fatty liver disease. BMC Med Genet 11: 172, 2010. PMID: 21176169. DOI: 10.1186/1471-2350-11-172

54 Seko Y, Sumida Y, Tanaka S, Mori K, Taketani H, Ishiba H, Hara T, Okajima A, Umemura A, Nishikawa T, Yamaguchi K, Moriguchi M, Kanemasa K, Yasui K, Imai S, Shimada K and Itoh Y: Development of hepatocellular carcinoma in Japanese patients with biopsy-proven non-alcoholic fatty liver disease: Association between PNPLA3 genotype and hepatocarcinogenesis/fibrosis progression. Hepatol Res 47(11): 1083-1092, 2017. PMID: 27862719. DOI: 10.1111/hepr.12840

55 Liu YL, Patman GL, Leathart JB, Piguet AC, Burt AD, Dufour JF, Day CP, Daly AK, Reeves HL and Anstee QM: Carriage of the PNPLA3 rs738409 $\mathrm{C}>\mathrm{G}$ polymorphism confers an increased risk of non-alcoholic fatty liver disease associated hepatocellular carcinoma. J Hepatol 61(1): 75-81, 2014. PMID: 24607626. DOI: $10.1016 /$ j.jhep.2014.02.030

56 Kawaguchi T, Shima T, Mizuno M, Mitsumoto Y, Umemura A, Kanbara Y, Tanaka S, Sumida Y, Yasui K, Takahashi M, Matsuo K, Itoh Y, Tokushige K, Hashimoto E, Kiyosawa K, Kawaguchi M, Itoh H, Uto H, Komorizono Y, Shirabe K, Takami S, Takamura T, Kawanaka M, Yamada R, Matsuda F and Okanoue T: Risk estimation model for nonalcoholic fatty liver disease in the Japanese using multiple genetic markers. PLoS One 13(1): e0185490, 2018. PMID: 29385134. DOI: 10.1371/journal. pone. 0185490
57 Bianco C, Jamialahmadi O, Pelusi S, Baselli G, Dongiovanni P, Zanoni I, Santoro L, Maier S, Liguori A, Meroni M, Borroni V, D’Ambrosio R, Spagnuolo R, Alisi A, Federico A, Bugianesi E, Petta S, Miele L, Vespasiani-Gentilucci U, Anstee QM, Stickel F, Hampe J, Fischer J, Berg T, Fracanzani AL, Soardo G, Reeves H, Prati D, Romeo S and Valenti L: Non-invasive stratification of hepatocellular carcinoma risk in non-alcoholic fatty liver using polygenic risk scores. J Hepatol 74(4): 775782, 2021. PMID: 33248170. DOI: 10.1016/j.jhep.2020.11.024

58 Gellert-Kristensen H, Richardson TG, Davey Smith G, Nordestgaard BG, Tybjaerg-Hansen A and Stender S: Combined effect of PNPLA3, TM6SF2, and HSD17B13 variants on risk of cirrhosis and hepatocellular carcinoma in the general population. Hepatology 72(3): 845-856, 2020. PMID: 32190914. DOI: $10.1002 /$ hep. 31238

59 Serfaty L: Follow-up of patients with chronic hepatitis $\mathrm{C}$ and a sustained viral response. Liver Int 36(Suppl 1): 67-71, 2016. PMID: 26725900. DOI: 10.1111/liv.13016

60 Peleg N, Issachar A, Sneh Arbib O, Cohen-Naftaly M, Harif Y, Oxtrud E, Braun M, Leshno M, Barsheshet A and Shlomai A: Liver steatosis is a major predictor of poor outcomes in chronic hepatitis $\mathrm{C}$ patients with sustained virological response. J Viral Hepat 26(11): 1257-1265, 2019. PMID: 31243878. DOI: 10.1111/jvh.13167

61 Miki D, Akita T, Kurisu A, Kawaoka T, Nakajima T, Hige S, Karino Y, Toyoda H, Kumada T, Tsuge M, Hiramatsu A, Imamura M, Aikata $\mathrm{H}$, Hayes $\mathrm{CN}$, Honda $\mathrm{K}$, Seike M, Akuta N, Kobayashi M, Kumada H, Tanaka J and Chayama K: PNPLA3 and HLA-DQB1 polymorphisms are associated with hepatocellular carcinoma after hepatitis $\mathrm{C}$ virus eradication. $\mathrm{J}$ Gastroenterol 55(12): 1162-1170, 2020. PMID: 33057914. DOI: 10.1007/s00535-020-01731-6

62 Nishikawa $\mathrm{H}$, Enomoto $\mathrm{H}$, Nishiguchi $\mathrm{S}$ and Iijima $\mathrm{H}$ : Sarcopenic obesity in liver cirrhosis: possible mechanism and clinical impact. Int J Mol Sci 22(4): 1917, 2021. PMID: 33671926. DOI: $10.3390 /$ ijms 22041917

63 Wojciechowska J, Krajewski W, Bolanowski M, Kręcicki T and Zatoński T: Diabetes and cancer: a review of current knowledge. Exp Clin Endocrinol Diabetes 124(5): 263-275, 2016. PMID: 27219686. DOI: $10.1055 / \mathrm{s}-0042-100910$

64 Naka Y, Okada T, Nakagawa T, Kobayashi E, Kawasaki Y, Tanaka Y, Tawa H, Hirata Y, Kawakami K, Kakimoto K, Inoue T, Takeuchi T, Fukunishi S, Hirose Y, Uchiyama K, Asahi M and Higuchi K: Enhancement of $O$-linked $\mathrm{N}$-acetylglucosamine modification promotes metastasis in patients with colorectal cancer and concurrent type 2 diabetes mellitus. Oncol Lett 20(2): 1171-1178, 2020. PMID: 32724357. DOI: 10.3892/ol.2020.11665

65 Burney S, Irfan K, Saif MW and Masud F: Diabetes and pancreatic cancer. JOP 15(4): 319-321, 2014. PMID: 25076332. DOI: $10.6092 / 1590-8577 / 2680$

66 Fang HJ, Shan SB, Zhou YH and Zhong LY: Diabetes mellitus and the risk of gastrointestinal cancer in women compared with men: a meta-analysis of cohort studies. BMC Cancer 18(1): 422, 2018. PMID: 29661174. DOI: 10.1186/s12885-018-4351-4

67 Wang P, Kang D, Cao W, Wang Y and Liu Z: Diabetes mellitus and risk of hepatocellular carcinoma: a systematic review and meta-analysis. Diabetes Metab Res Rev 28(2): 109-122, 2012. PMID: 21898753. DOI: 10.1002/dmrr.1291

68 Wang C, Wang X, Gong G, Ben Q, Qiu W, Chen Y, Li G and Wang L: Increased risk of hepatocellular carcinoma in patients 
with diabetes mellitus: a systematic review and meta-analysis of cohort studies. Int J Cancer 130(7): 1639-1648, 2012. PMID: 21544812. DOI: $10.1002 /$ ijc. 26165

69 Chen J, Han Y, Xu C, Xiao T and Wang B: Effect of type 2 diabetes mellitus on the risk for hepatocellular carcinoma in chronic liver diseases: a meta-analysis of cohort studies. Eur J Cancer Prev 24(2): 89-99, 2015. PMID: 24809655. DOI: 10.1097/CEJ.0000000000000038

70 Yang WS, Va P, Bray F, Gao S, Gao J, Li HL and Xiang YB: The role of pre-existing diabetes mellitus on hepatocellular carcinoma occurrence and prognosis: a meta-analysis of prospective cohort studies. PLoS One 6(12): e27326, 2011. PMID: 22205924. DOI: 10.1371/journal.pone.0027326

71 Han H, Zhang T, Jin Z, Guo H, Wei X, Liu Y, Chen Q and He $\mathrm{J}$ : Blood glucose concentration and risk of liver cancer: systematic review and meta-analysis of prospective studies. Oncotarget 8(30): 50164-50173, 2017. PMID: 28432278. DOI: 10.18632 /oncotarget.16816

72 Wang YG, Wang P, Wang B, Fu ZJ, Zhao WJ and Yan SL: Diabetes mellitus and poorer prognosis in hepatocellular carcinoma: a systematic review and meta-analysis. PLoS One 9(5): e95485, 2014. PMID: 24830459. DOI: 10.1371/journal.pone. 0095485

73 Li LJ, Li GD, Wei HL, Chen J, Liu YM, Li F, Xie B, Wang B and $\mathrm{Li} \mathrm{CL}$ : Insulin resistance reduces sensitivity to Cisplatinum and promotes adhesion, migration and invasion in HepG2 cells. Asian Pac J Cancer Prev 15(7): 3123-3128, 2014. PMID: 24815457. DOI: 10.7314/apjcp.2014.15.7.3123

74 Tateishi R, Matsumura T, Okanoue T, Shima T, Uchino K, Fujiwara N, Senokuchi T, Kon K, Sasako T, Taniai M, Kawaguchi T, Inoue H, Watada H, Kubota N, Shimano H, Kaneko S, Hashimoto E, Watanabe S, Shiota G, Ueki K, Kashiwabara K, Matsuyama Y, Tanaka H, Kasuga M, Araki E, Koike K and LUCID study investigators: Hepatocellular carcinoma development in diabetic patients: a nationwide survey in Japan. J Gastroenterol 56(3): 261273, 2021. PMID: 33427937. DOI: 10.1007/s00535-020-01754-Z

75 Zhou YY, Zhu GQ, Liu T, Zheng JN, Cheng Z, Zou TT, Braddock M, Fu SW and Zheng MH: Systematic review with network meta-analysis: antidiabetic medication and risk of hepatocellular carcinoma. Sci Rep 6: 33743, 2016. PMID: 27642100. DOI: 10.1038/srep33743

76 Ahmed Mobasher M, Galal El-Tantawi H and Samy El-Said K: Metformin ameliorates oxidative stress induced by diabetes mellitus and hepatocellular carcinoma in rats. Rep Biochem Mol Biol 9(1): 115-128, 2020. PMID: 32821759. DOI: 10.29252/rbmb.9.1.115

77 Gao C, Fang L, Zhang H, Zhang WS, Li XO and Du SY: Metformin induces autophagy via the AMPK-mTOR signaling pathway in human hepatocellular carcinoma cells. Cancer Manag Res 12: 5803-5811, 2020. PMID: 32765083. DOI: 10.2147/CMAR.S257966

78 Mobasher MA, Germoush MO, Galal El-Tantawi H and Samy El-Said K: Metformin improves biochemical and pathophysiological changes in hepatocellular carcinoma with pre-existed diabetes mellitus rats. Pathogens 10(1): 59, 2021. PMID: 33440701. DOI: 10.3390/pathogens 10010059

79 Kawaguchi T, Kohjima M, Ichikawa T, Seike M, Ide Y, Mizuta T, Honda K, Nakao K, Nakamuta M and Sata M: The morbidity and associated risk factors of cancer in chronic liver disease patients with diabetes mellitus: a multicenter field survey. J
Gastroenterol 50(3): 333-341, 2015. PMID: 24912965. DOI: 10.1007/s00535-014-0968-5

80 Kennedy OJ, Roderick P, Buchanan R, Fallowfield JA, Hayes PC and Parkes J: Coffee, including caffeinated and decaffeinated coffee, and the risk of hepatocellular carcinoma: a systematic review and dose-response meta-analysis. BMJ Open 7(5): e013739, 2017. PMID: 28490552. DOI: 10.1136/bmjopen-2016013739

81 Contaldo F, Santarpia L and Pasanisi F: Chronic inflammatory liver diseases and coffee intake. Curr Opin Clin Nutr Metab Care 22(5): 389-392, 2019. PMID: 31219824. DOI: 10.1097/ MCO.0000000000000586

82 Nishikawa H, Enomoto $\mathrm{H}$, Nishiguchi $\mathrm{S}$ and Iijima H: Liver cirrhosis and sarcopenia from the viewpoint of dysbiosis. Int $\mathbf{J}$ Mol Sci 21(15): 5254, 2020. PMID: 32722100. DOI: 10.3390/ ijms 21155254

83 Ley RE, Turnbaugh PJ, Klein S and Gordon JI: Microbial ecology: human gut microbes associated with obesity. Nature 444(7122): 1022-1023, 2006. PMID: 17183309. DOI: $10.1038 / 4441022 \mathrm{a}$

84 Nishikawa H, Enomoto H, Ishii A, Iwata Y, Miyamoto Y, Ishii N, Yuri Y, Hasegawa K, Nakano C, Nishimura T, Yoh K, Aizawa N, Sakai Y, Ikeda N, Takashima T, Takata R, Iijima H and Nishiguchi S: Elevated serum myostatin level is associated with worse survival in patients with liver cirrhosis. J Cachexia Sarcopenia Muscle 8(6): 915-925, 2017. PMID: 28627027. DOI: $10.1002 /$ jcsm. 12212

85 Shida T, Oshida N, Suzuki H, Okada K, Watahiki T, Oh S, Kim $\mathrm{T}$, Isobe T, Okamoto Y, Ariizumi SI, Yamamoto M and Shoda J: Clinical and anthropometric characteristics of non-obese nonalcoholic fatty liver disease subjects in Japan. Hepatol Res 50(9): 1032-1046, 2020. PMID: 32602214. DOI: 10.1111/hepr.13543

86 Cani PD, Amar J, Iglesias MA, Poggi M, Knauf C, Bastelica D, Neyrinck AM, Fava F, Tuohy KM, Chabo C, Waget A, Delmée E, Cousin B, Sulpice T, Chamontin B, Ferrières J, Tanti JF, Gibson GR, Casteilla L, Delzenne NM, Alessi MC and Burcelin R: Metabolic endotoxemia initiates obesity and insulin resistance. Diabetes 56(7): 1761-1772, 2007. PMID: 17456850. DOI: $10.2337 / \mathrm{db} 06-1491$

87 Finlin BS, Zhu B, Boyechko T, Westgate PM, Chia CW, Egan $\mathrm{JM}$ and Kern PA: Effect of rifaximin treatment on endotoxemia and insulin sensitivity in humans. J Endocr Soc 3(9): 16411651, 2019. PMID: 31428718. DOI: 10.1210/js.2019-00148

88 Fukunishi S, Sujishi T, Takeshita A, Ohama H, Tsuchimoto Y, Asai A, Tsuda Y and Higuchi K: Lipopolysaccharides accelerate hepatic steatosis in the development of nonalcoholic fatty liver disease in Zucker rats. J Clin Biochem Nutr 54(1): 39-44, 2014. PMID: 24426189. DOI: 10.3164/jcbn.13-49

89 Fang W, Xue H, Chen X, Chen K and Ling W: Supplementation with sodium butyrate modulates the composition of the gut microbiota and ameliorates high-fat diet-induced obesity in mice. J Nutr 149(5): 747-754, 2019. PMID: 31004166. DOI: $10.1093 / \mathrm{jn} / \mathrm{nxy} 324$

90 Moreira AP, Texeira TF, Ferreira AB, Peluzio Mdo C and Alfenas Rde C: Influence of a high-fat diet on gut microbiota, intestinal permeability and metabolic endotoxaemia. Br J Nutr 108(5): 801-809, 2012. PMID: 22717075. DOI: 10.1017/S0007 114512001213

91 Yoshimoto S, Loo TM, Atarashi K, Kanda H, Sato S, Oyadomari S, Iwakura Y, Oshima K, Morita H, Hattori M, 
Honda K, Ishikawa Y, Hara E and Ohtani N: Obesity-induced gut microbial metabolite promotes liver cancer through senescence secretome. Nature 499(7456): 97-101, 2013. PMID: 23803760. DOI: 10.1038 /nature 12347

92 Nishikawa H, Shiraki M, Hiramatsu A, Moriya K, Hino K and Nishiguchi S: Japan Society of Hepatology guidelines for sarcopenia in liver disease (1st edition): Recommendation from the working group for creation of sarcopenia assessment criteria. Hepatol Res 46(10): 951-963, 2016. PMID: 27481650. DOI: $10.1111 /$ hepr.12774

93 Kohara K: Sarcopenic obesity in aging population: current status and future directions for research. Endocrine 45(1): 1525, 2014. PMID: 23821364. DOI: 10.1007/s12020-013-9992-0

94 Grillot J, D'Engremont C, Parmentier AL, Lakkis Z, Piton G, Cazaux D, Gay C, De Billy M, Koch S, Borot S and Vuitton L: Sarcopenia and visceral obesity assessed by computed tomography are associated with adverse outcomes in patients with Crohn's disease. Clin Nutr 39(10): 3024-3030, 2020. PMID: 31980183. DOI: 10.1016/j.clnu.2020.01.001

95 Öztürk ZA, Türkbeyler İH, Abiyev A, Kul S, Edizer B, Yakaryılmaz FD and Soylu G: Health-related quality of life and fall risk associated with age-related body composition changes; sarcopenia, obesity and sarcopenic obesity. Intern Med J 48(8): 973-981, 2018. PMID: 29665258. DOI: 10.1111/imj.13935

96 Follis S, Cook A, Bea JW, Going SB, Laddu D, Cauley JA, Shadyab AH, Stefanick ML and Chen Z: Association between sarcopenic obesity and falls in a multiethnic cohort of postmenopausal women. J Am Geriatr Soc 66(12): 2314-2320, 2018. PMID: 30375641. DOI: 10.1111/jgs. 15613

97 Kobayashi A, Kaido T, Hamaguchi Y, Okumura S, Shirai H, Yao S, Kamo N, Yagi S, Taura K, Okajima H and Uemoto S: Impact of sarcopenic obesity on outcomes in patients undergoing hepatectomy for hepatocellular carcinoma. Ann Surg 269(5): 924-931, 2019. PMID: 29064889. DOI: 10.1097/SLA.0000000000002555

98 Itoh S, Yoshizumi T, Kimura K, Okabe H, Harimoto N, Ikegami T, Uchiyama H, Shirabe K, Nishie A and Maehara Y: Effect of sarcopenic obesity on outcomes of living-donor liver transplantation for hepatocellular carcinoma. Anticancer Res 36(6): 3029-3034, 2016. PMID: 27272822.
99 Barazzoni R, Bischoff S, Boirie Y, Busetto L, Cederholm T, Dicker D, Toplak H, Van Gossum A, Yumuk V and Vettor R: Sarcopenic obesity: time to meet the challenge. Obes Facts 11(4): 294-305, 2018. PMID: 30016792. DOI: 10.1159/ 000490361

100 Japanese BMI and mortality risk. Available at: http:// epi.ncc.go.jp/can_prev/evaluation/2830.html, written in Japanese. [Last accessed on March 20, 2021]

101 Sasazuki S, Inoue M, Iwasaki M, Sawada N, Shimazu T, Yamaji T, Tsugane S and JPHC Study Group: Combined impact of five lifestyle factors and subsequent risk of cancer: the Japan Public Health Center Study. Prev Med 54(2): 112-116, 2012. PMID: 22155160. DOI: 10.1016/j.ypmed.2011.11.003

102 Multipurpose cohort study (JPHC Study). Available at: https://epi.ncc.go.jp/jphc/, written in Japanese [Last accessed on April 16, 2021]

103 Arterburn DE, Telem DA, Kushner RF and Courcoulas AP: Benefits and risks of bariatric surgery in adults: a review. JAMA 324(9): 879-887, 2020. PMID: 32870301. DOI: 10.1001/jama.2020.12567

104 Wiggins T, Antonowicz SS and Markar SR: Cancer risk following bariatric surgery-systematic review and meta-analysis of national population-based cohort studies. Obes Surg 29(3): 1031-1039, 2019. PMID: 30591985. DOI: 10.1007/s11695-0183501-8

105 Njei B, McCarty TR, Sharma P, Lange A, Najafian N, Ngu JN, Ngomba VE and Echouffo-Tcheugui JB: Bariatric surgery and hepatocellular carcinoma: a propensity score-matched analysis. Obes Surg 28(12): 3880-3889, 2018. PMID: 30069863. DOI: $10.1007 / \mathrm{s} 11695-018-3431-5$

106 Kwak M, Mehaffey JH, Hawkins RB, Hsu A, Schirmer B and Hallowell PT: Bariatric surgery is associated with reduction in non-alcoholic steatohepatitis and hepatocellular carcinoma: A propensity matched analysis. Am J Surg 219(3): 504-507, 2020. PMID: 31575419. DOI: 10.1016/j.amjsurg.2019.09.006

Received April 9, 2021

Revised April 16, 2021

Accepted April 19, 2021 